\title{
SELECTION OF MINERS
}

\section{A SURVEY OF SCHOOL-LEAVERS IN A VALLEY IN SOUTH WALES}

\author{
BY \\ I. T. T. HIGGINS AND P. D. OLDHAM, WITH THE ASSISTANCE OF A. J. MERRICK \\ Pneumoconiosis Research Unit (Cardiff) \\ AND \\ M. I. DUNSDON \\ Burden Mental Research Department (Bristol)
}

Investigations carried out by this Unit have suggested that miners and ex-miners, whose chest radiographs show no pneumoconiosis, differ in physique and lung ventilatory function from men of comparable age in other occupations. Miners have usually been found to be shorter and lighter and to have a lower average ventilatory capacity than men who have never mined. Such differences are most marked in the 55-64 age group and are less in younger men. These differences may be due either to selection or to the mining environment. It is impossible to say if selection occurred in the past; but it is possible by comparing mining entrants with boys who take up other occupations to determine if it is occurring at the present time. In addition, it should be possible to find out if mining has any effect by comparing the two groups as they grow older.

In an attempt to answer some of these questions, an investigation of school-leavers in the Rhondda Fach Valley in South Wales has been started. We hoped that the initial examination of the boys, consisting in anthropometric and ventilatory capacity measurements, would answer the question of selection. We also proposed to follow the careers of these boys, repeating the various measurements periodically, in order to assess the influence of age, occupation, military training, and chronic respiratory disease on their development.

In addition to the physical and physiological examination, we also included a mental assessment using a short mental test (Dunsdon and Fraser Roberts, 1955).

The results of the initial study are now complete and it is possible to make some observations on the type of boy going into mining in the Rhondda Fach.

\section{Procedure}

We decided to examine those boys living in the Rhondda Fach who left school at the end of the summer term, 1954.

Boys who live in the Rhondda Fach go to one of six schools: Ferndale Grammar, Ferndale Secondary, and Hendrefadog Secondary situated within the little Rhondda, and Porth Grammar, Rhondda County Grammar, and Islwyn Secondary situated outside the little Rhondda. There are thus three grammar schoolso and three secondary modern schools. In addition, a few boys receive a general education at the Rhondda Technical Institute in Llwynypia.

During the course of the Easter term, the headmasters of these schools were visited, the purpose of the investigation explained to them, and preliminary arrangements made. A list of the boys expected to leave at the end of the summer term was obtained. This list included dates of birth, addresses, and the occupations of the boys' fathers. A list of boys who were mentally or physically handicapped and who would in normal circumstances be leaving school at the end of the term was obtained from the Medical Officer of Health, Rhondda Urban District Council. There were eight of these, five physically and three mentally handicapped. On visiting their homes, it was found that five of the eight had already left school.

\section{METHODS}

ANTHRopometric MEASUREMENTS.-Standing and sitting height were recorded to the nearest half inch and weight to the nearest pound. The boys were wearing trousers and socks and a deduction of one pound was made for clothing. Bicondylar diameters of humerus and femur were measured to the nearest millimetre. Girths of the arm with the biceps maximally flexed and of the calf with the subject standing were measured at the widest point to the nearest $\frac{1}{4}^{\prime \prime}$. Three fat measurements, taken over the middle of the back of the arm, the right angle of the scapula, and the anterior abdominal wall $2^{\prime \prime}$ above the 
anterior superior iliac spine, were taken with Harpenden Skinfold Calipers (Edwards, Hammond, Healy, Tanner, and Whitehouse, 1955). These calipers maintain a constant pressure at all openings of the jaws. The pressure used in the present investigation was $7.5 \mathrm{~g} . / \mathrm{mm}^{2}$. Bi-acromial and bi-iliac diameters and antero-posterior and transverse diameters of the chest were recorded with calipers to the nearest half centimetre.

Physiological Measurements.-Ventilatory capacity was measured by recording the volume of air expelled during the first 0.75 second of a forced expiration, using a modified Gaensler (1951) apparatus. The mean of three or four readings was taken and the resulting volume is expressed as the (indirect) maximum voluntary ventilation (M.V.V.) as described by Kennedy (1953). A single vital capacity (V.C.) measurement was made, usually at the same time as the second or third timed volume measurement. Twenty boys from Ferndale Secondary School were examined on two occasions to determine the repeatability of the measurements.

RADIOGRAPHY. $-X$ rays of the chest were taken of all boys, using a mobile $x$-ray van. Each boy had a full sized postero-anterior film and in addition a special "macro" film of the right side of the chest. Enlargement for this film was obtained by moving the subject towards the micro focus tube (focal spot $0.3 \mathrm{~mm}$.) so that he was $24^{\prime \prime}$ from the cassette, which was kept at the normal anode-film distance of $60^{\prime \prime}$. A K.V. of 120 peak voltage and 1.8 milliampère-seconds was used with standard films and high voltage intensifying screens. Development was standard and automatic.

Mental Testing.-The test used for intelligence grading was a combination of four already well-established verbal scales, all of which have been shown to have a high correlation with mental age (Terman and Merrill, 1937; Raven, 1938; Wechsler, 1949; Dunsdon and Fraser Roberts, 1953) and to intercorrelate with each other to the extent of from $\cdot 83$ to $\cdot 87$ (Dunsdon and Fraser Roberts, 1955). The combined scales, given orally and individually, provide a good measure for the rapid grading and comparison of large groups (Dunsdon and Fraser Roberts, 1955). The test has manifest advantages over other types of test in respect of reliability and validity (Terman and Merrill, 1937; Raven, 1938; Wechsler, 1949), relative elimination of coaching and practice effects, and applicability to subjects of all grades of intelligence and educational level.

At the beginning of the Michaelmas term, the schools were again visited, and those boys who had been examined as expected to leave were checked against those who had actually left. Any additional boys who had left unexpectedly were examined and $\boldsymbol{x}$-rayed.

\section{RESULTS}

NuMBERS.-At the end of the summer term, 1954, 102 Rhondda Fach boys left school: 36 from grammar schools, 48 from secondary schools, and fifteen from the Rhondda Technical Institute. Three were mentally or physically handicapped boys who would have left school at this time in normal circumstances. The breakdown of these numbers according to age and school is given in Table $I$.

TABLE I

SCHOOL-LEAVERS (SUMMER, 1954)

\begin{tabular}{|c|c|c|c|c|c|c|c|}
\hline \multirow{2}{*}{ School } & \multicolumn{6}{|c|}{ Age (yrs) } & \multirow{2}{*}{$\begin{array}{c}\text { Total } \\
\text { Number } \\
\text { of Boys }\end{array}$} \\
\hline & 14 & 15 & 16 & 17 & 18 & 19 & \\
\hline $\begin{array}{lc}\text { Porth Grammar .. } \\
\text { Rhondda County } \\
\text { Ferndale Grammar } \\
\text { Rhondda Technical } \\
\text { Islwyn Secondary Modern } \\
\text { Ferndale Secondary } \\
\text { Modern } \\
\text { Hendrefadog Secondary } \\
\text { Mandicapped Boys } \\
\text { Hodern }\end{array}$ & $\begin{array}{r}-7 \\
\frac{1}{5} \\
12 \\
7 \\
2\end{array}$ & $\begin{array}{r}-4 \\
6 \\
8 \\
6 \\
10 \\
8 \\
\end{array}$ & $\begin{array}{l}\overline{2} \\
2 \\
7 \\
- \\
- \\
-\end{array}$ & $\begin{array}{l}-1 \\
6 \\
- \\
- \\
-\end{array}$ & $\begin{array}{l}2 \\
10 \\
- \\
- \\
-\end{array}$ & $\begin{array}{l}\frac{1}{1} \\
- \\
- \\
-\end{array}$ & $\begin{array}{r}1 \\
9 \\
26 \\
15 \\
11 \\
22 \\
15 \\
3\end{array}$ \\
\hline Total & 27 & 42 & 12 & 7 & 12 & 2 & 102 \\
\hline
\end{tabular}

REPEATABILITY.-It was found that the measurements were fairly repeatable. Table II shows the standard error of a single measurement, or where more appropriate (when measurements were made to the nearest $\frac{1}{4}$ or $\left.\frac{1}{2}^{\prime \prime}\right)$ the percentage of subjects in whom there was agreement for the twenty boys on whom duplicate measurements were made.

TABLE II

REPEATABILITY OF MEASUREMENTS

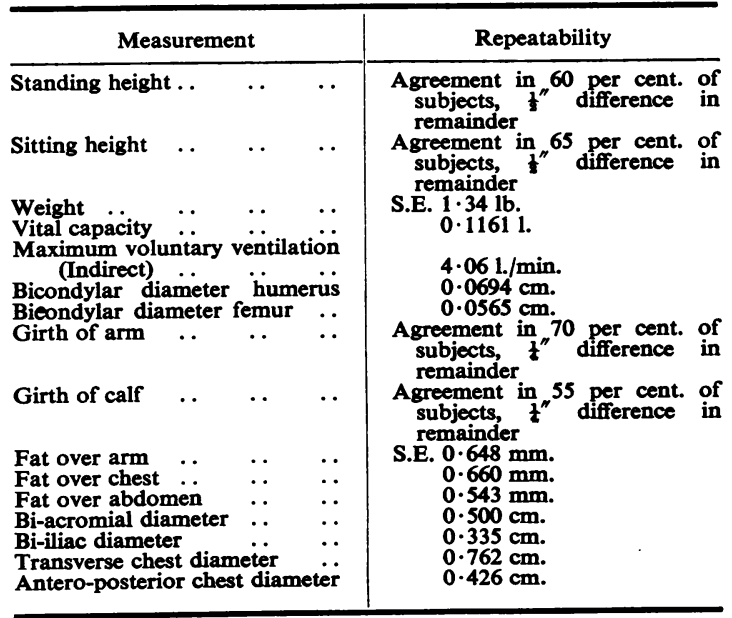

MiNerS.-Those boys who started at one of the two training centres for miners at Wattstown or Aberaman are considered to have taken up mining for the purpose of this analysis. An arbitrary definition is the only possible one. The group is likely to be a changing one; men who start training 
may not complete it, and even if they complete it they may not necessarily enter the mines. Also boys who have first tried other jobs may finally enter mining. All that is really possible is to review the population at various times after they cease to be schoolboys. The present review was made after 3 months, when nineteen out of the 102 schoolleavers had entered mining.

Anthropometric and Physiological Results.Table III shows the mean values of height, weight, maximum voluntary ventilation, vital capacity, and mental test score, and Table IV the mean values of the other measurements in the 14, 15, and 16-year-old boys, according to whether they took up mining or some other occupation. It will be seen that of 27 boys aged 14 years, twelve took up mining and fifteen some other occupation. The mean ages in months of the two groups were close. The miners were slightly taller, the mean standing height being $\frac{1}{2}$ " and the sitting height $1^{\prime \prime}$ greater, and they had a higher average M.V.V. and V.C., $8 \cdot 51 . / \mathrm{min}$. and
0.34 1. greater respectively, than the others. None of these differences approach significance even at the 5 per cent. level. In the 15-year-old group, of which only six went into mining, statistically insignificant differences of $1 \cdot 3$ and $1 \cdot 0^{\prime \prime}$ were obtained in the standing and sitting heights respectively. There was, however, a weight difference of nearly $16 \mathrm{lb}$. This difference in weight is statistically significant $(0.05>P>0.02)$ and, if allowance is made for the slight differences in age of the boys in the two groups, the significance is enhanced $(0.01>P>0.001)$. The larger bone and girth measurements in the miners combined with smaller skinfold thicknesses suggest that the difference in weight was due to bone and muscle development rather than to obesity.

The one 16-year-old who took up mining was $2 \cdot 5^{\prime \prime}$ and $1 \cdot 5^{\prime \prime}$ above the group means for the 16-year-olds, he was $40 \mathrm{lb}$. heavier, and his V.C. and M.V.V. were 1.541 . and $11.01 . / \mathrm{min}$. larger.

Table V (opposite) shows the mean values by type of school. It will be seen that among the 15 -year-olds the grammar and secondary schoolboys

TABLE III

MEAN VALUES FOR MAIN MEASUREMENTS AT EACH AGE ACCORDING TO OCCUPATION

\begin{tabular}{|c|c|c|c|c|c|c|c|c|c|c|c|c|}
\hline & & & & \multicolumn{3}{|c|}{ 14-year-olds } & \multicolumn{3}{|c|}{ 15-year-olds } & \multicolumn{3}{|c|}{ 16-year-olds } \\
\hline \multicolumn{4}{|c|}{ Age Group } & Miners & Others & $\begin{array}{c}\text { All } \\
\text { Leavers }\end{array}$ & Miners & Others & $\begin{array}{c}\text { All } \\
\text { Leavers }\end{array}$ & Miners & Others & $\begin{array}{c}\text { All } \\
\text { Leavers }\end{array}$ \\
\hline Number & $\ldots$ & . & $\ldots$ & 12 & 15 & 27 & 6 & 36 & 42 & 1 & 11 & 12 \\
\hline \multicolumn{3}{|c|}{ Months since last birthday } & $\ldots$ & $10 \cdot 8$ & $10 \cdot 5$ & $10 \cdot 6$ & $1 \cdot 3$ & $3 \cdot 7$ & $3 \cdot 3$ & $1 \cdot 0$ & $3 \cdot 2$ & $3 \cdot 2$ \\
\hline \multicolumn{2}{|c|}{ Standing height (in.) } & $\cdots$ & $\cdots$ & $63 \cdot 6$ & $63 \cdot 1$ & $63 \cdot 3$ & $65 \cdot 9$ & $64 \cdot 7$ & $64 \cdot 9$ & $69 \cdot 3$ & $66 \cdot 4$ & $66 \cdot 7$ \\
\hline \multicolumn{2}{|c|}{ Sitting height (in.) } & . & $\cdots$ & $33 \cdot 7$ & $32 \cdot 7$ & $33 \cdot 2$ & $34 \cdot 7$ & $33 \cdot 7$ & $33 \cdot 8$ & $36 \cdot 3$ & $34 \cdot 6$ & $34 \cdot 8$ \\
\hline Weight (lb.) & $\cdots$ & $\cdots$ & $\cdots$ & $109 \cdot 7$ & $109 \cdot 3$ & $109 \cdot 5$ & $126 \cdot 5$ & $110 \cdot 7$ & $112 \cdot 9$ & $176 \cdot 0$ & $127 \cdot 5$ & $131 \cdot 5$ \\
\hline \multicolumn{2}{|c|}{ Vital capacity (1.) } & $\cdots$ & $\cdots$ & $3 \cdot 80$ & $3 \cdot 46$ & $3 \cdot 61$ & $4 \cdot 21$ & $3 \cdot 74$ & $3 \cdot 80$ & $5 \cdot 84$ & $4 \cdot 16$ & $4 \cdot 30$ \\
\hline \multicolumn{4}{|c|}{ Maximum voluntary ventilation } & $118 \cdot 8$ & $110 \cdot 3$ & $114 \cdot 1$ & $126 \cdot 3$ & $117 \cdot 1$ & $118 \cdot 4$ & $152 \cdot 0$ & $140 \cdot 1$ & $141 \cdot 1$ \\
\hline Mental test s & & $\ldots$ & $\cdots$ & $66 \cdot 2$ & $61 \cdot 2$ & $63 \cdot 3$ & $73 \cdot 2$ & $76 \cdot 9$ & $76 \cdot 3$ & $91 \cdot 0$ & $95 \cdot 2$ & $95 \cdot 1$ \\
\hline
\end{tabular}

TABLE IV

MEAN VALUES FOR ADDITIONAL ANTHROPOMETRIC MEASUREMENTS AT EACH AGE ACCORDING TO OCCUPATION

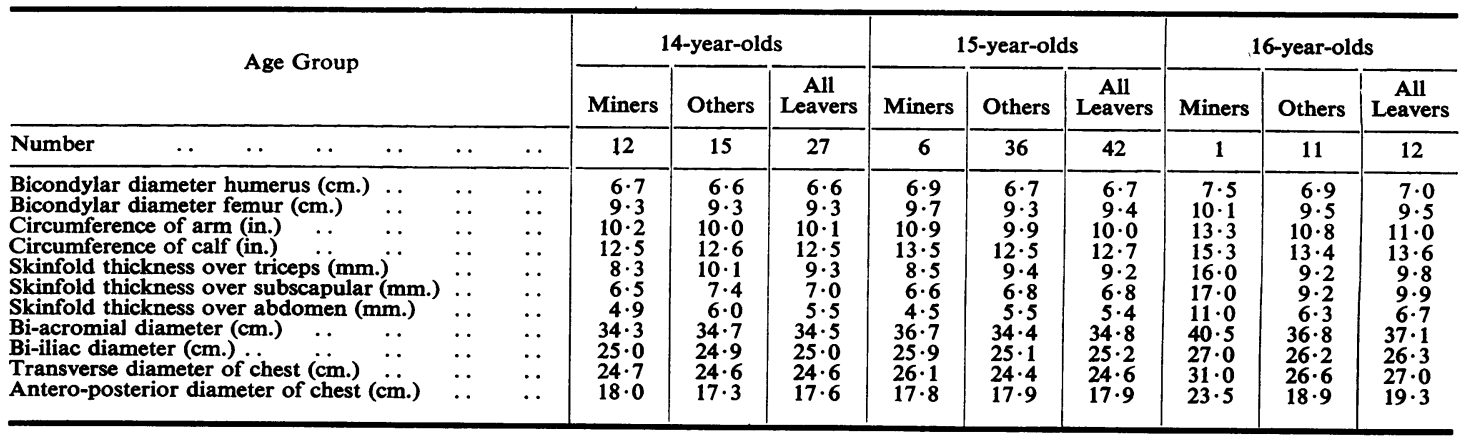


TABLE V

MEAN VALUES FOR DIFFERENT TYPES OF SCHOOL

\begin{tabular}{|c|c|c|c|c|c|c|c|c|}
\hline \multicolumn{4}{|c|}{ Type of School } & Grammar & Secondary & Technical & $\begin{array}{l}\text { Mentally or } \\
\text { Physically }\end{array}$ & Total \\
\hline $\begin{array}{l}15- \\
\text { year- } \\
\text { olds }\end{array}$ & $\begin{array}{l}\text { Number } \\
\text { Months since last birthday } \\
\text { Standing height (in.) } \quad \ldots \\
\text { Sitting height (in.) } \\
\text { Weight (lb.) } \\
\text { Vital capacity (1.) } \\
\text { Maximum voluntary ventila } \\
\text { Mental test score }\end{array}$ & $\begin{array}{cc} & \cdots \\
\cdots & \cdots \\
\ldots & \cdots \\
\cdots & \cdots \\
\ddot{i o n} & (1 . / \min .) \\
\cdots & \cdots\end{array}$ & $\begin{array}{l}\cdots \\
\cdots \\
\cdots \\
\cdots \\
\cdots \\
\cdots\end{array}$ & $\begin{array}{c}10 \\
6 \cdot 6 \\
64 \cdot 4 \\
33 \cdot 7 \\
111 \cdot 5 \\
3 \cdot 65 \\
113 \cdot 5 \\
93 \cdot 6\end{array}$ & $\begin{array}{r}24 \\
0 \cdot 7 \\
64 \cdot 7 \\
33 \cdot 5 \\
111 \cdot 5 \\
3 \cdot 73 \\
116 \cdot 8 \\
67 \cdot 7\end{array}$ & $\begin{array}{c}8 \\
7 \cdot 1 \\
66 \cdot 1 \\
34 \cdot 6 \\
119 \cdot 0 \\
4 \cdot 20 \\
129 \cdot 5 \\
79 \cdot 6\end{array}$ & $\begin{array}{l}\text { Z } \\
\bar{z} \\
\bar{z}\end{array}$ & $\begin{array}{c}42 \\
3 \cdot 3 \\
64 \cdot 9 \\
33 \cdot 8 \\
113 \cdot 0 \\
3 \cdot 80 \\
118 \cdot 4 \\
76 \cdot 3\end{array}$ \\
\hline $\begin{array}{l}\text { 16- } \\
\text { year- } \\
\text { olds }\end{array}$ & $\begin{array}{l}\text { Number } \\
\text { Months since last birthday } \\
\text { Standing height (in.) } \\
\text { Sitting height (in.) } \\
\text { Weight (lb.) } \\
\text { Vital capacity (1.) } \\
\text { Maximum voluntary ventila } \\
\text { Mental test score }\end{array}$ & $\begin{array}{cc}\ldots & \ldots \\
\ldots & \ldots \\
\ldots & \cdots \\
\ldots & \cdots \\
\ddot{i o n} & (1 . / \min .) \\
\ldots & \ldots\end{array}$ & $\begin{array}{l}\cdots \\
\cdots \\
\cdots \\
\cdots \\
\cdots \\
\cdots\end{array}$ & $\begin{array}{c}4 \\
3 \cdot 0 \\
68 \cdot 3 \\
35 \cdot 8 \\
141 \cdot 0 \\
4 \cdot 95 \\
154 \cdot 0 \\
96 \cdot 0\end{array}$ & $\begin{array}{l}0 \\
z \\
z \\
z\end{array}$ & $\begin{array}{r}7 \\
3 \cdot 3 \\
66 \cdot 3 \\
34 \cdot 3 \\
125 \cdot 9 \\
3 \cdot 89 \\
131 \cdot 0 \\
85 \cdot 1\end{array}$ & $\begin{array}{c}1 \\
3 \cdot 0 \\
62 \cdot 8 \\
33 \cdot 8 \\
133 \cdot 0 \\
4 \cdot 60 \\
159 \cdot 0 \\
91 \cdot 0\end{array}$ & $\begin{array}{c}12 \\
3 \cdot 2 \\
66 \cdot 7 \\
34 \cdot 8 \\
131 \cdot 5 \\
4 \cdot 30 \\
141 \cdot 1 \\
89 \cdot 3\end{array}$ \\
\hline
\end{tabular}

were evenly matched, but that the boys from the technical college were on the average bigger and had larger ventilatory measurements. Among the 16-year-olds, however, the advantage was with the grammar school boys. There were no secondary modern schoolboys at this age for comparison.

Mental Tests.-98 out of the 102 leavers were given the mental test. The mean scores of those in the 14 to 16-year-old groups are given in Table III.

The scores of boys (mainly from secondary modern schools) who entered mining were fairly randomly distributed among their colleagues. In the 14-yearold group, the mean score for boys entering mining was slightly higher and in the 15-year-old group slightly lower, than the mean group scores for those who left to enter other occupations. These mean score differences were however without statistical significance.

The one 16-year-old who took up mining obtained a score that was close to the mean for other leavers in his age group.

CHest RADIOGRAPHY.- One boy was found to have an increase of the hilar shadow thought to be possibly due to tuberculous adenitis. $\mathrm{He}$ was referred to the Pontypridd Chest Clinic where a repeat $x$ ray a few weeks later was reported normal. His Mantoux test was negative to $0.1 \mathrm{ml} .1: 1000$ old tuberculin. No radiological abnormality was found in any of the other boys.

The macro films, an innovation, were hard to read in view of our lack of any standard for comparison. Further work is in progress to compare these, presumably normal, films with those of men who have been exposed to dust and who show less than Category 1/- -/- simple pneumoconiosis.
Social FACTORS.-The occupations adopted by the leavers are shown in Table VI.

TABLE VI

OCCUPATIONS OF BOYS ON FIRST INQUIRY IN SEPTEMBER, 1954

\begin{tabular}{|c|c|c|c|c|c|c|}
\hline $\begin{array}{l}\text { Further } \\
\text { Education }\end{array}$ & $\begin{array}{l}\text { University } \\
\text { Other . }\end{array}$ & $\begin{array}{l}\cdots \\
\cdots\end{array}$ & $\ddot{x}$ & $\ddot{*}$ & $\begin{array}{r}11 \\
2\end{array}$ & 13 \\
\hline $\begin{array}{l}\text { Armed Services } \\
\text { and } \\
\text { Police }\end{array}$ & $\begin{array}{l}\text { Army } \\
\text { Royal Air For } \\
\text { Awaiting call- }\end{array}$ & & $\begin{array}{l}\cdots \\
\cdots \\
\cdots\end{array}$ & $\begin{array}{l}\cdots \\
\cdots\end{array}$ & $\begin{array}{l}\mathbf{2} \\
\mathbf{2} \\
\mathbf{3}\end{array}$ & 7 \\
\hline $\begin{array}{l}\text { Industry and } \\
\text { Commerce }\end{array}$ & $\begin{array}{l}\text { Mining .. } \\
\text { Apprenticed } \\
\text { Factory work } \\
\text { Locally in sho } \\
\text { Tailoring }\end{array}$ & $\begin{array}{l}\ddot{p} \\
\ddot{p} \\
\cdots\end{array}$ & $\begin{array}{l}\cdots \\
\cdots \\
\cdots \\
\cdots\end{array}$ & $\begin{array}{l}\cdots \\
\cdots \\
\cdots \\
\cdots\end{array}$ & $\begin{array}{r}19 \\
11 \\
14 \\
12 \\
3\end{array}$ & 61 \\
\hline Clerk & $\begin{array}{l}\text { Junior clerk or } \\
\text { Bank clerk } \\
\text { Bookmaker's }\end{array}$ & $\begin{array}{l}\text { n railws } \\
\text { clerk }\end{array}$ & $\begin{array}{l}\text { ay } \\
\cdots \\
\cdots\end{array}$ & $\begin{array}{l}\cdots \\
\cdots \\
\cdots\end{array}$ & $\begin{array}{l}2 \\
1 \\
1\end{array}$ & 4 \\
\hline Building Labourer & . & $\ldots$ & $\cdots$ & . & $\cdots$ & 2 \\
\hline Warehouse or Store & room Worker & $\cdots$ & $\cdots$ & $\ldots$ & $\ldots$ & 2 \\
\hline Bar Attendant $\ldots$ & $\cdots$ & $\cdots$ & $\cdots$ & $\cdots$ & . & 1 \\
\hline Moved out of the & rea & $\cdots$ & $\cdots$ & $\cdots$ & $\cdots$ & 2 \\
\hline Unemployed & $\cdots$ & $\cdots$ & $\cdots$ & $\cdots$ & $\cdots$ & 10 \\
\hline Total $\quad \ldots$ & $\cdots$ & $\cdots$ & $\cdots$ & $\cdots$ & $\cdots$ & 102 \\
\hline
\end{tabular}

Each mining trainee was interviewed at the training centre and asked why he had taken up mining. The following reasons were given:

1. Family or friends in mining (including one boy whose "buddies told him it was nice"). This was the most frequent reason.

2. Tried other work and did not like it.

3. Tried to get other work and failed.

4. Money. Only one boy gave this reason.

5. One day off for study each week. 
Information was available about the occupations and chest radiographs of the fathers of the schoolleavers as a result of previous surveys of this valley (Cochrane, Cox, and Jarman, 1952, 1955). It is interesting to compare the proportion of miners among fathers and sons (Table VII). It will be seen that 3 months after leaving school, under 20 per cent. of the boys had taken up mining, compared with nearly 80 per cent. of their fathers. This difference may change with the passage of time as boys who have first tried other occupations become miners. It is interesting to observe that whether or not a boy took up mining was independent of the occupation of his father. The numbers that would be expected on a proportional basis are shown in Table VII in parentheses.

TABLE VII

FATHERS AND SONS IN MINING

\begin{tabular}{|c|c|c|c|c|c|c|}
\hline \multirow{3}{*}{\multicolumn{2}{|c|}{$\begin{array}{c}\text { Fathers' } \\
\text { Occupation }\end{array}$}} & \multicolumn{5}{|c|}{ Sons' Occupation } \\
\hline & & \multicolumn{2}{|c|}{ Mining } & \multicolumn{2}{|c|}{ Other } & \multirow{2}{*}{$\begin{array}{c}\text { Tota } \\
\text { No. }\end{array}$} \\
\hline & & No. & Expected & No. & Expected & \\
\hline Mining .. & .. & 17 & $(15 \cdot 3)$ & 65 & $(66 \cdot 7)$ & 82 \\
\hline Other .. & .. & 2 & $(3 \cdot 0)$ & 14 & $(13 \cdot 0)$ & 16 \\
\hline Not known & . & $\mathbf{0}$ & $(0 \cdot 7)$ & 4 & $(3 \cdot 3)$ & 4 \\
\hline Total $\quad$. & .. & 19 & & 83 & & 102 \\
\hline
\end{tabular}

Classification of the chest $x$ rays of those of the fathers who were miners is given in Table VIII. Unfortunately readings were not available for eight. Of the 33 fathers whose $x$ rays showed no pneumoconiosis, nine sons $(27 \cdot 2$ per cent.) took up mining, of the $\mathbf{4 1}$ fathers with pneumoconiosis, seven sons (17.1 per cent.) took up mining: Though this suggests that boys whose fathers have pneumoconiosis take up other occupations in preference to mining, the difference is not statistically significant.

TABAE VIII

CATEGORY OF PNEUMOCONHOSLS AMONG MINING FATHERS

\begin{tabular}{|c|c|c|c|c|c|}
\hline \multirow{2}{*}{\multicolumn{3}{|c|}{$\begin{array}{l}\text { Fathers' } \\
X \text {-Ray Category } \\
\text { of Pneumoconiosis }\end{array}$}} & \multicolumn{3}{|c|}{ Sons' Occupation } \\
\hline & & & \multirow{2}{*}{$\frac{\text { Mining }}{9}$} & \multirow{2}{*}{$\begin{array}{c}\text { Other } \\
24 \\
\end{array}$} & \multirow{2}{*}{$\frac{\text { Total }}{33}$} \\
\hline None .. & $\cdots$ & $\cdots$ & & & \\
\hline Simple . . & $\cdots$ & $\cdots$ & 4 & 20 & 24 \\
\hline Complicated & $\cdots$ & $\cdots$ & 3 & 14 & 17 \\
\hline$X$ ray not kno & $\overline{w n}$ & . & 1 & 7 & 8 \\
\hline Total & $\cdots$ & . & 17 & 65 & 82 \\
\hline
\end{tabular}

\section{Discussion}

The problem of past selection has been considered by various authors. D'Arcy Hart (1942) concluded that there was no difference in height and weight between normal miners and non-mining controls. His non-mining sample was however small and no allowance was made for age in the comparison. In the Ministry of Food Survey of 1943 (Kemsley, 1950), miners aged 15-19 years were found to be shorter and slightly lighter than other industrial workers in the same age group.

Investigations carried out at this Unit suggest that Rhondda Fach miners are smaller and lighter than men in other occupations of comparable age. For example in a detailed study of miners and agebalanced controls (Gilson, Hugh-Jones, Oldham, and Meade, 1955), it was found that on the average miners without pneumoconiosis were over $\mathbf{1}^{\prime \prime}$ shorter and between 7 and $15 \mathrm{lb}$. lighter, in each of three age groups, than men who had never mined. Differences were also observed in the ventilatory capacities: the maximum breathing capacity was 10 to $241 . / \mathrm{min}$. and the vital capacity 0.34 to 0.831 . less in the mining groups. In a more recent investigation of a random sample of miners, ex-miners, and non-miners carried out in the Rhondda Fach, differences in stem height and weight were observed in the 55 to 64-year-old group, but not in the 25 to 34-year-old men. Ventilatory capacity measurements on the other hand were lower in the miners than in the non-miners in both age groups, but the difference was more striking in the older men. The anthropometric differences were not confirmed in a random sample of men aged 55 to 64 in Leigh in Lancashire, and they may therefore be characteristic of the Rhondda Fach. Significantly lower ventilatory capacity measurements were however found in Leigh in miners compared with men who had never mined.

In the present investigation the boys who took up mining were not smaller, lighter, or physiologically less able than those who took up other occupations. The results suggest that, on the contrary, although other social factors are undoubtedly also involved in the choice of occupation, the bigger and more muscular boys are more likely to take up mining. It should, however, be mentioned that this difference could be due to the mining boys being more advanced in adolescence.

The differences that have been observed in previous surveys may have been due to past selection. Certainly alternative occupations were far fewer in the time of the fathers of the present group, as is well shown from the different proportion of the elder men who became miners, 
approximately 80 per cent. compared with 19 per cent. On the other hand it is possible that environmental factors may have been responsible, partially if not wholly. The follow-up of these boys should provide valuable information on this point.

Mental Test.-Norms for the combined tests, permitting the elimination of age differences, are not available beyond the age of 15 years. Raw scores can however be used in this particular survey because:

1. Comparisons are made in year groups.

2. Within these groups, the differences in mean age at test, between those entering mining and the remainder of leavers, are small.

3. Differences in average performance within groups are small.

Among the boys in the 14-year-old group, who had left school as soon as they were legally entitled to do so, the mining entrants appeared to have a slight intellectual advantage over other leavers of comparable age. The mean score difference of five words (Table III) was not however significant $(t=0.8958$; $0.4>P>0.3)$. The miners were, however, on average 1.5 months younger than the other leavers. At age 15 years exactly, this would correspond to 0.8 word; the score difference should therefore be increased by something of this order. Even making this adjustment for age which would slightly widen the gap, the difference is well below the 5 per cent. level of significance.

In the 15-year-old group, the mean score for miners was slightly below that for other leavers, but the difference was even less than that found in the 14-year-old group. In the 15-year-old group, the non-miners are at an average disadvantage of 3.73 words. The miners are $2 \cdot 3$ months younger than the other leavers, and so, using the same regression as before, the difference should be adjusted to 4.9 words. This difference is far below the 5 per cent. level of significance.

Any comparison of miners with other leavers according to type of school attended is possible only for boys in the 15-year-old group, since none but secondary schoolleavers were in the 14-year-old group and, among the 16-year-old leavers, only one handicapped boy had left from a secondary school. Mean scores for all mining and other leavers in the 15 -year-old group are given according to school in Table IX. From this it may be seen that the test differentiated quite well between the secondary modern school boys and those of comparable age who had left from other types of schools. Numbers are too small, however, to allow the statistical significance of the differences to be given except as
TABLE IX

MENTAL TEST MEAN SCORES (15-YEAR-OLD GROUP)

\begin{tabular}{|c|c|c|c|c|c|}
\hline \multirow{2}{*}{\multicolumn{3}{|c|}{ Type of School }} & \multicolumn{3}{|c|}{ Leavers } \\
\hline & & & \multirow{2}{*}{$\begin{array}{c}\text { Miners } \\
72 \cdot 50 \\
74 \cdot 50 \\
-\end{array}$} & \multirow{2}{*}{$\begin{array}{l}\text { Others } \\
66 \cdot 68 \\
81 \cdot 33 \\
93.60\end{array}$} & \multirow{2}{*}{$\begin{array}{c}\text { All } \\
67 \cdot 70 \\
79 \cdot 63 \\
93 \cdot 60\end{array}$} \\
\hline $\begin{array}{l}\text { Secondary } \\
\text { Technical } \\
\text { Grammar }\end{array}$ & & $\begin{array}{l}. \\
\cdots\end{array}$ & & & \\
\hline All & .. & .. & $73 \cdot 17$ & $76 \cdot 88$ & $76 \cdot 34$ \\
\hline
\end{tabular}

between secondary modern boys and those from technical and grammar schools combined. The difference in this case is highly significant $(P>\cdot 001)$.

\section{Conclusions}

Whatever the reason for the differences in anthropometric and physiological measurements between miners and ex-miners and men who had never worked in the mines which have been recorded previously at this Unit, the present investigation offers no evidence that selection of miners in favour of the boys who are smaller, lighter, and less physiologically able is occurring now. On the contrary, this investigation suggests that there is a tendency for the bigger and more muscular boys with larger ventilatory capacities to go into the pits. That this is a subjective reason and that there are other more consciously obvious directives, such as relatives or friends in the job, money, or lack of suitable alternatives, is probable from the answers obtained to the question why the boys took up mining.

The intelligence of the mining entrants was not significantly different from that of other leavers of comparable age in the area studied.

\section{SUMMARY}

An investigation has been carried out into the problem of selection for mining.

School-leavers living in the Rhondda Fach have been examined anthropometrically, physiologically, and mentally to determine if those who take up mining differ from the rest of the population.

Mean heights, weights, M.V.V., and V.C. were larger in the mining groups at each of three ages. These differences were not significant, except in the case of weight in the 15-year-old group, which was significant at the 5 per cent. level $(.05>P>\cdot 02)$. This difference of weight appeared to be due to the greater bone and muscle development in the miners.

The meptal ability of the boys taking up mining was average for boys from secondary modern schools in the area. 
Our thanks are due to Dr. D. J. Thomas, Medical Officer of Health, and Mr. Morris Jones, Director of Education, Rhondda Urban District, and to the headmasters of the schools concerned for their help and co-operation. It is a pleasure to acknowledge the advice of Dr. J. M. Tanner who kindly read the manuscript; the helpful criticism of our colleagues at the Pneumoconiosis Research Unit, particularly Dr. J. C. Gilson, the Director, and Dr. A. L. Cochrane; and the assistance of Mr. W. G. Clarke and the Unit's radiological and epidemiological survey teams.

\section{REFERENCES}

Cochrane, A. L., Cox, J. G., and Jarman, T. F. (1952). Brit. med. J., $2,843$. (1955). Ibid, 1, 371.
Dunsdon, M.I., and Roberts, J. A. Fraser (1953). Brit. J. stat. Psychol., 6, 61-70. (1955). Ibid., 8, 3.

Edwards, D. A. W., Hammond, W. H., Healy, M. J. R., Tanner, J. M., and Whitehouse, R. H. (1955). Brit. J. Nutrit., 9, 133. Gaensler, E. A. (1951). Science, 114, 444.

Gilson, J. C., Hugh-Jones, P., Oldham, P. D., and Meade, F. (1955). M.R.C. Spec. Rep. Ser., No. 290. H.M.S.O., London.

Hart, P. D'Arcy, and Aslett, E. A. (1942). M.R.C. Spec. Rep. Ser., No. 243. H.M.S.O., London.

Kemsley, W. F. F. (1950). Ann. Eugen. (Camb.), 15, 161.

Kennedy, M. C. S. (1953). Thorax, 8, 73.

Raven, J. C. (1938). "The Mill Hill Vocabulary Scale." Lewis, London.

Terman, L. M., and Merrill, M. A. (1937). "Measuring Intelligence." Harrap, London.

Wechsler, D. (1949). "Wechsler Intelligence Scale for Children." Psychological Corp., New York. 